\title{
Treatment of epilepsy in the elderly people
}

\author{
A Siniscalchi \\ From de Senectute: Age and Health Forum \\ Catanzaro, Italy. 5-7 December 2009
}

The pharmacokinetics and pharmacodynamics of antiepileptic drugs (AEDs) differ in old age from those in younger patients. Age-related changes in pharmacokinetics play a role as early as the drug absorption stage, because gastric secretion, blood volume, blood flow, and gastrointestinal motility are all lower in old age. The serum concentration of the medications is heavily influenced by protein binding, mainly of serum albumin, whose concentration is markedly reduced in old age, so that the free fraction of medication in the serum is higher. This influences not only the desired medication effects, but also the undesired ones, and is particularly important in the case of highly protein-bound antiepileptic drugs such as valproic acid, phenytoin, or carbamazepine. In elderly patients a reduction of hepatic and renal function were observed. No guidelines, systematic reviews, or meta-analyses on this subject are available. There have been only three randomized, controlled, double-blind therapeutic trials of evidence class I or II regarding epilepsy in the elderly, as well as a number of smaller studies of classes IIa and III. Thus, many clinical decisions about antiepileptic treatment in old age are based on extrapolations of experience and data obtained from younger patients, combined with the general principles of pharmacotherapy in old age. The treatment of epilepsy seems to be successful in the elderly more often than in young adults. A precondition for successful treatment, however, is that the antiepileptic drug is well tolerated and does not interact with other, concurrently taken, medications. The treatment of epilepsy in an elderly patient generally requires searching for the medication that is best tolerated and least metabolized. Problems can arise because drug-drug interactions must be considered in the elderly people that often take multiple medications. It is evident that the so-called enzyme-inducing antiepileptic drugs (carbamazepine, phenytoin, phenobarbital) generally cannot be

Department of Neuroscience, Neurology Division, "Annunziata" Hospital, Cosenza, Italy recommended for use in elderly patients because of their multifarious interaction. Moreover these AEDs may facilitate the development of osteoporosis and cannot be recommended for use in elderly woman patients. Recently, clinical studies have shown a better tolerability of never antiepileptic drugs. In conclusion numerous factors must be considered in treating elderly patients for seizures, but maximizing the ability of patients to tolerate drug therapy is often the basis for AED selection.

Published: 19 May 2010

doi:10.1186/1471-2318-10-S1-L47

Cite this article as: Siniscalchi: Treatment of epilepsy in the elderly people. BMC Geriatrics 2010 10(Suppl 1):L47.
Submit your next manuscript to BioMed Central and take full advantage of:

- Convenient online submission

- Thorough peer review

- No space constraints or color figure charges

- Immediate publication on acceptance

- Inclusion in PubMed, CAS, Scopus and Google Scholar

- Research which is freely available for redistribution

Submit your manuscript at www.biomedcentral.com/submit
C Biomed Central 